International Journal on Emerging Mathematics Education (IJEME)

Vol. 1, No. 2, September 2017, pp. 135-146

P-ISSN: 2549-4996, E-ISSN: 2548-5806, DOI: http://dx.doi.org/10.12928/ijeme.v1i2.5659

\title{
Using APOS Theory Framework: Why Did Students Unable to Construct a Formal Proof?
}

\author{
1Syamsuri, ${ }^{2}$ Purwanto, ${ }^{2}$ Subanji, ${ }^{2}$ Santi Irawati \\ ${ }^{1}$ Universitas Sultan Ageng Tirtayasa, Jalan Raya Jakarta Km 4 Serang, Indonesia \\ 2Universitas Negeri Malang, Jalan Semarang 5 Malang, Indonesia \\ e-mail: syamsuri@untirta.ac.id
}

\begin{abstract}
Abstrak
Berpikir matematis sangat dibutuhkan dalam belajar matematika, apalagi di perguruan tinggi. Salah satu aktifitas belajar matematika ialah pembuktian matematis. Penelitian ini mendeskripsikan proses berpikir mahasiswa yang gagal mengonstruksi bukti-matematis formal. Analisis dalam deskripsi tersebut menggunakan Teori APOS dalam menjelaskan struktur mental dan mekanisme mental yang muncul ketika melakukan pembuktian matematis. Penelitian ini menggunakan pendekatan kualitatif. Penelitian ini melibatkan 26 mahasiswa pendidikan matematika di salah satu perguruan tinggi di Banten, Indonesia. Data diperoleh melalui think-aloud ketika menyelesaikan tugas pembuktian dan dilanjutkan dengan wawancara berbasis tugas. Hasil penelitian ini menyatakan bahwa mahasiswa gagal mengonstruksi bukti matematis formal karena proses berpikir mahasiswa tersebut hanya melalui tahapan interiorisasi masalah, interiorisasi objek, dan koordinasi. Dengan demikian, mekanisme mental lainnya, seperti: enkapsulasi, de-enkapsulasi dangeneralisasi belum muncul. Hal tersebut menunjukkan bahwa struktur mental Action telah terbentuk, namun Process dan Object belum muncul. Oleh karena itu perlu dipertimbangkan suatu strategi pembelajaran yang mendukung mekanisme mental yang dibutuhkan dalam mengonstruksi bukti.
\end{abstract}

Kata Kunci: proses berpikir, konstruki bukti, pembuktian, bukti matematis, teori APOS

\begin{abstract}
Mathematical thinking is necessary for mathematics learning, especially in undergraduate level. One of the activities in undergraduate mathematics learning is proving. This article describes students' thinking process who unable to construct a mathematical formal proof. The description uses APOS Theory to explore students' mental mechanism and students' mental structure while they do proving. This research is qualitative research that conducted on 26 students majored in mathematics education in public university in Banten province, Indonesia. Data was obtained using think-aloud when solving the proving task and then interview based the task. Results show that the students could not construct a formal proof because the mental mechanism that appeared was interiorization and coordination. Based on the results, some suitable learning activities should be designed to support the construction of these mental mechanisms.
\end{abstract}

Keywords: thinking process, proof-construction, proving, proof, APOS theory

How to Cite: Syamsuri, Purwanto, Subanji, \& Irawati, S. (2017). Using APOS theory framework: Why did students unable to construct a formal proof?. International Journal on Emerging Mathematics Education, 1(2), 135-145. http://dx.doi.org/10.12928/ijeme.v1i2.5659

\section{INTRODUCTION}

Thinking activities is important in mathematics learning. Thinking in mathematics learning relates to mathematical processes, i.e.: specializing, generalizing, conjecturing, and convincing (Mason, Burton \& Stacey, 2010). In addition, mathematical thinking is important because mathematics learning must develops a 
mathematical reasoning (Kilpatrick, Swafford \& Findell, 2002; NCTM, 2000; Mason et al., 2010). Moreover, National Council of Teachers of Mathematics (NCTM) recommended a learning which encourages mathematical reasoning (NCTM, 2000). In Principles and Standards for School Mathematics, NCTM stated that mathematics curriculum involve : (1) recognize reasoning and proof as fundamental aspects of mathematics; (2) make and investigate mathematical conjectures; (3) develop and evaluate mathematical arguments and proofs; and (4) select and use various types of reasoning and methods of proof.

Some researches explored thinking process in undergraduate mathematics learning (Dreyfus, 1991; Tall, 1992; Cai, 2000; Tall, 2002; Dreyfus, 2002; Dubinsky \& Tall, 2002; Dubinsky, 2002; Jäppinen, 2005; Tall, 2008; Aziz, Pramudiani \& Purnomo, 2017). Tall (1992) suggested that students in university have experienced a transition to advance mathematical thinking. According to Dreyfus (1991), advance mathematical thinking are process in representing, visualizing, generalizing, classifying, conjecturing, inducing, analyzing, synthesizing, abstracting or formalizing.

Many students have difficulties in proof construction (Moore, 1994; Gibson, 1998; Baker \& Campbell, 2004; Weber, 2006; Selden \& Selden, 2003; Sowder \& Harel, 2003). The difficulties consist of uncompleted conceptual understanding and incorrect proving strategy. Other researches explained how to evaluate proof construction (Andrew, 2009; Mejia-Ramos, Fuller, Weber, Rhoads \& Samkoff, 2012; Syamsuri, Purwanto, Subanji \& Irawati, 2016). Andrew (2009) created Proof Errors Evaluation Tools (PEET). And also, Mejia-Ramos et al. (2012) developed an assessment model for proof comprehensionin undergraduate mathematics. They stated that the model described ways to assess students' understanding of seven different aspects of a proof. These types of assessment are: (1) Meaning of terms and statements, (2) Logical status of statements and proof framework, (3) Justification of claims, (4) Summarizing via high-level ideas, (5) Identifying the modular structure, (6) Transferring the general ideas or methods to another context, and (7) Illustrating with examples. In addition, Syamsuri et al. (2016) developed a quadrant model to describe students' classification of proof production. Figure 1 describes the quadrant model.

\begin{tabular}{|c|c|}
\hline $\begin{array}{l}\text { Puadrant II } \\
\text { Insufficient concept in formal-proof } \\
\text { construction } \\
\text { - Rich Concept Image (CI) } \\
\text { - Poor connection between CI and } \\
\text { Concept Definition (CD) } \\
\text { - Correct Proof-structure } \\
\text { - Reflective commentary focuses on } \\
\text { procedural }\end{array}$ & $\begin{array}{l}\text { Quadrant I } \\
\text { Correct Proof Construction } \\
\text { - Rich Concept Image (CI) } \\
\text { - Good connection between CI and } \\
\text { Concept Definition (CD) } \\
\text { - reflective commentary focuses on } \\
\text { understanding of the structure } \\
\text { Conceptual-Understanding }\end{array}$ \\
\hline $\begin{array}{l}\text { Quadrant III } \\
\text { Insufficient concept and Incorrect proof- } \\
\text { structure in formal-proof construction } \\
\text { - Enough CI } \\
\text { - Poor connection between CI and CD } \\
\text { - Unable to appear proof-structure } \\
\text { - Reflective commentary focuses on } \\
\text { procedural }\end{array}$ & $\begin{array}{l}\text { Quadrant IV } \\
\text { Incorrect proof-structure in formal-proof } \\
\text { construction } \\
\text { - Enough CI } \\
\text { - Poor connection between CI and CD } \\
\text { - Incorrect Proof-structure } \\
\text { - Reflective commentary focuses on the } \\
\text { procedural }\end{array}$ \\
\hline
\end{tabular}

Figure 1. Quadrant Model of Students Formal-Proof Construction (Syamsuri et al., 2016)

IJEME, Vol. 1, No. 2, September 2017, 135-146 
The quadrant model classifies proof construction based on thinking process. Therefore, investigation of thinking process or outcome of thinking process is necessary for selecting an appropriate learning strategies. Many prior researches revealed outcome thinking process about proof construction. For instance, a students have difficulties in proof construction (Moore, 1994; Gibson, 1998; Baker \& Campbell, 2004; Weber, 2006) and so students made errors in proof construction (Selden \& Selden, 2003; Sowder \& Harel, 2003). Nevertheless, researches which reveal mental structures and mental mechanisms are rarely found. Whereas knowing students' thinking process that consisting of both mental structures and mental mechanisms can help teachers or lecturers in order to give an appropriate learning assistance. Some suitable learning activities should be designed to support the construction of this thinking process. In addition, if students' thinking process is incorrect, then refinement thinking process can be easy in order to it does not occur in next learning. Based on the explanation above, this article describes students' thinking process who unable constructing a formal proof. If students didn't construct a formal proof then they have an insufficient concept and incorrect proof structure in formal proof construction. So, this article will describe thinking process for Quadrant III (Figure 1). Hence, the description includes why student unable constructing a formal proof.

\section{RESEARCH METHOD}

This research used a qualitative approach, because of: (1) researcher as a key instrument, (2) inductive data analysis, and (3) holistic account. According to Creswell (2012), these research characteristics which done in this research is called qualitative research.

\section{Participants}

This research is a descriptive exploratory study to reveal why students could not construct a formal proof. Therefore, research approach used is qualitative. The research conducted on 26 students majored in mathematics education in public university in Banten province, Indonesia. The consideration of that was students were able to think a formal proof in mathematics. Students who could not construct a formal proof was selected as a research subject.

\section{Instruments}

The main instrument in qualitative research was researcher itself. The support instruments are proving-task and interview guides. These instruments were evaluated and validated from two lecturers in order to guarantee the quality of instruments. The interview is open and it's needed to reveal students' response about the error in constructing a proof. Procedure to obtain data are 1) subject is given the task proving and asked him/her to accomplish the task by think-aloud. And then 2) subject is interviewed base on-the-task. Therefore, the scratch of proving-task and transcript of the interview is obtained. The proving-task is in the following.

Prove: For any positive integers $m \& n$, if $m^{2}$ and $n^{2}$ are divisible by 3 , then $m+n$ is divisible by 3.

We used this task because some methods can use for solving, i.e.: direct proof, contradiction, and contrapositive. Besides, we would like to test students' comprehension about mathematical induction method, because some students have an opinion that using mathematical induction to prove a number which "divisible by 3 ". 


\section{Data Analyze}

Data obtained are recording of think-aloud, scratch of proving-task-sheet, and recording of interview. These data was collected to describe students' thinking process in constructing a proof. Therefore, the reliability of this research is a source of data.

To analyze students' thinking process, we use APOS theory. In APOS theory, the main mental mechanisms for building the mental structures of action, process, object, and schema are called interiorization and encapsulation (Weller et al., 2003). The mental structures of action, process, object, and schema constitute the acronym APOS. APOS theory postulates that a mathematical concept develops as one tries to transform existing physical or mental objects. Figure 2 shows how student's mental structure and the mental mechanism works in APOS Theory (Arnon et al., 2014). The descriptions of action, process, object and schema in this research are given below:

- Action: A transformation is first conceived as an action, when it is a reaction to stimuli which an individual perceives as external. Action's indicator is a student has given some correct example for the proposition.

- Process: As an individual repeat and reflects on an action, it may be interiorized into a mental process. A process is a mental structure that performs the same operation as the action, but wholly in the mind of the individual. Process' indicator is students could create mathematical equation model into any variable.

- Object: If one becomes aware of a process as a totality, realizes that transformations can act on that totality and can actually construct such transformations (explicitly or in one's imagination), then we say the individual has encapsulated the process into a cognitive object. For example, students could create other representation from mathematical equation model in order to connect to other information in the proposition.

- Schema: A mathematical topic often involves many actions, processes, and objects that need to be organized and linked into a coherent framework, called a schema. For example, there is good connection among integer concept, divisibility concept, the logic of implication in the proposition.

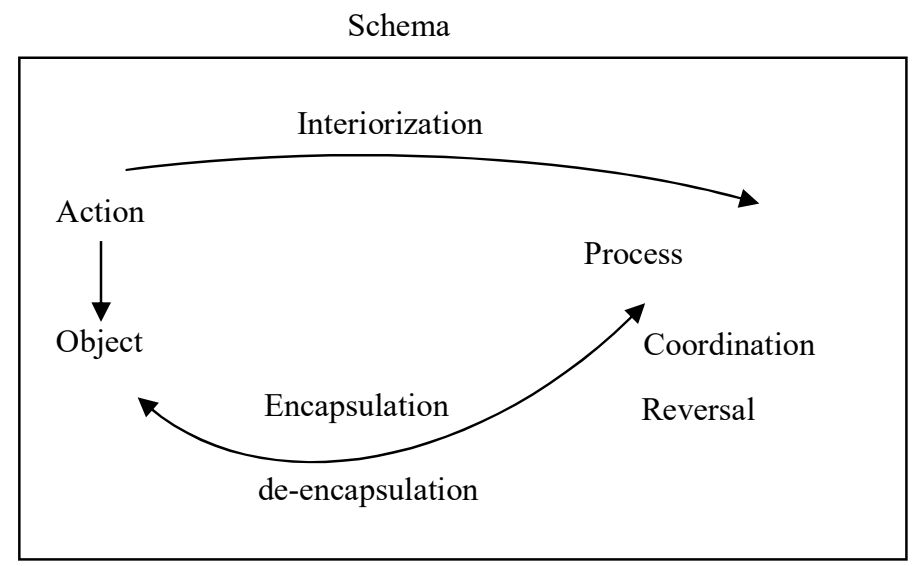

Figure 2. Mental Structure and Mental Mechanism in APOS Theory (Arnon, et al. 2014)

\section{RESULTS AND DISCUSSION}

Of the 26 students who were given the task of mathematical proof. There were twelve students who unable to construct formal proof. The students merely gave genericexamples which comply with the task. The students enabled to begin

IJEME, Vol. 1, No. 2, September 2017, 135-146 
constructing a formal proof. This article will describe thinking process of two subjects along constructing formal proof, namely: S1 and S2.

\section{Think Aloud Analysis of S1 Base on APOS Theory}

Subject S1 began constructing proof by reading the task "For any positive integers $m \& n$, if $m^{2}$ and $n^{2}$ are divisible by 3 , then $m+n$ is divisible by 3 ". It indicated that $\mathrm{S} 1$ tried to understand the proving problem. It also showed that interiorization process occurred in mind of S1. After that, S1 thought for a moment, then S1 said, "I supposed that $m$ and $n$ are equal to any integer positive". This step indicated that S1 done a coordination about mathematical object which used in this task. This coordination yielded an Action. Subject S1 mentioned a special number as example of the task, "supposed $m$ is 2 and $n$ is 3". And then, S1 also done coordination which related to what is known and what is shown in Figure 3. S1 said, "and then if $m^{2}$ and $n^{2}$ are divisible by 3 then $m+n$ is divisible by 3 too". According to yield of interioization and coordination which related to the task, S1 said "and then, I supposed that $m^{2}+n^{2}$ equal to $2^{2}$ add to $3^{2}$, and then 4 add to 9, and then yield 13 . And 13 is not divisible by 3, so for $m+n=2+3=5$, and 5 is not divisible by 3 too. And then the proving task is unproved".

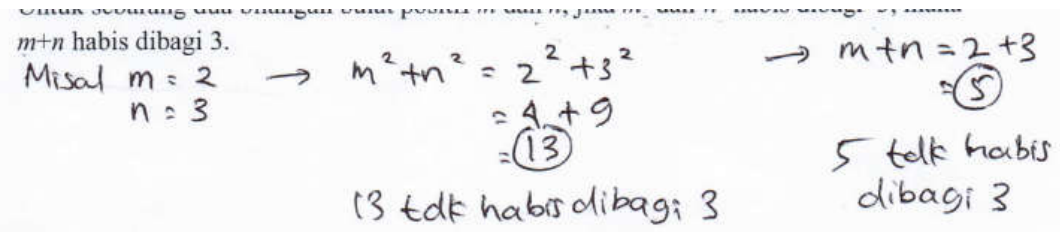

Figure 3. Student answer sheet

It indicated that coordination process of $\mathrm{S} 1$ is inappropriate because the process did not involve information that $\mathrm{m}^{2}$ and $\mathrm{n}^{2}$ are divisible by 3 . Besides, Action of $\mathrm{S} 1$ is inappropriate too, because S1 gave incorrect example, i.e.: $m=2$. After that, $S 1$ hesitated to ask the task "If $m^{2}$....... Sorry Sir, Should I solve again?".The first author permitted S1 to continue constructing a proof.

Subject S1 continued an interiorization and coordination by checking other integer number, Subject S1 said "supposed that $m$ is 2 , and $n$ is 3, then $m^{2}$ is $2^{2}$ and $n^{2}$ is $3^{2}=9^{\prime \prime}$. This given example is incorrect example shown in Figure 4. After that, S1 tried to reinforce interiorisation and coordination by reading the task, "if $m^{2}$ and $n^{2}$ are divisible by 3 then $m+n$ is divisible by 3". Nevertheless, S1's Action is incorrect, "We got 4 and 9, 9 is divisible by 3, but 4 is not divisible by 3, and then $m+n=2+3=5$ is not divisible by $3 "$.

$$
\begin{aligned}
& \text { Misal } \begin{array}{l}
m=2 \\
n=3
\end{array} \quad \begin{array}{l}
m^{2}=2^{2}=(4) \\
n^{2}=3^{2}=(9) \text { dan (9) }
\end{array} \text { habis dibagi } 3 \\
& \text { Maka tdk habis dibagi } 3
\end{aligned}
$$

Figure 4. Student incorrect answer

Mental structure of "Action" is created by S1, but mental structure of "Process" is uncreated. Subject S1 have done inductive generalization that the task is proved. S1 said "... and then the theorem is unproven. Finished, Sir". To know that S1 constructed 
proof base her competency of proving, then we asked to S1, "Are you sure?". S1's response is "I am not sure, Sir (that it is a formal proof)". It indicated that S1 knew that her proof construction is not formal-proof, so S1 was unsure.

\section{Think Aloud Analysis of S2 Based on APOS Theory}

Subject $\mathrm{S} 2$ began constructing proof by reading the task "For any positive integers $m$ \& $n$, if $m^{2}$ and $n^{2}$ are divisible by 3 , then $m+n$ is divisible by 3 ". It indicated that $\mathrm{S} 2$ stimulated her thought about the proving task (see Figure 5). It showed that interiorizationoccured in S2's thought. After that, S2 said " $m^{2}$ and $n^{2}$ are divisible by 3 then $m+n i$ divisible by 3 ". Subject S2 observed again the proving task, so it indicated that interiorization process still occurred. And then, Subject S2 has done coordination about a number which divisible by 3 as a mathematical object in this proof construction. S2 said, " $m^{2}$ is divisible by 3 and $n^{2}$ is too". Mental mechanism of coordination has been worked, " $m^{2}$ and $n^{2}$ are divisible by $3, m$ and $n$ are positive integers".

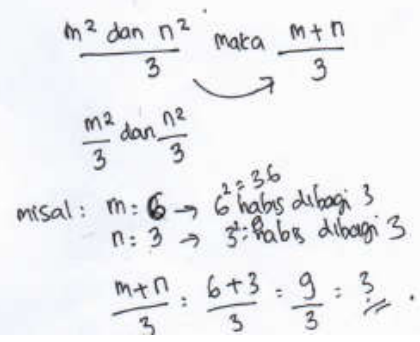

Figure 5. Student answer

Mental mechanism of interiorization has been occurred, S2 said "I supposed by example, let $m=2, n=3$ ". It showed that mental structure of "Action" is created. Nevertheless, Subject S2 has thought reflective-thinking, "Ooo...wait a moment, it must divisible by 3". Subject $S 2$ aware that she made a fault by taking positive integer $m=2$. So that $S 2$ read the proving task again, "For any positive integers $m \& n$, if $m^{2}$ and $n^{2}$ are divisible by 3 , then $m+n$ is divisible by 3". Subject S2 said ", it mean... the number is divisible by 3". Therefore, S2 replaced $m=2$ into $m=6$. Subject S2 mentioned "let $m=6,6$ is divisible by 3". Moreover, S2 has been done interiorization by verifying whether both $m$ and $n$ which selected are correct or incorrect shown in Figure 6. Subject S2 said "in this theorem, $m+n$ is divisible by 3, it means $(6+3) / 3=9 / 3=3$. Proved". Subject S2 done generalization merely using the example, "from the example, that is proven that $m+n i s$ divisible by $3 "$.

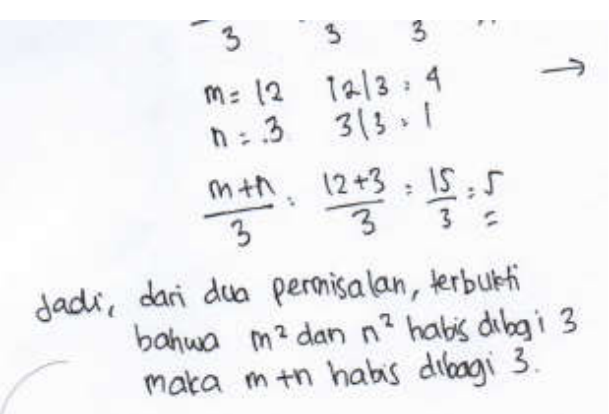

Figure 6. Mental mechanism of interiorization

After S2 created mental structure of "Action", then S2 thought interiorization again, "trying for another example, let $m$ is 12 , and $n$ is $3, m$ is divisible by $3,12 / 3=4$, and

IJEME, Vol. 1, No. 2, September 2017, 135-146 
$3 / 3=1$ ". This process indicated that S2's thought is inductive thinking. S2 merely verified the number whether correct or incorrect. So S2 said "it yields $(m+n) / 3=$ $(12+3) / 3=15 / 3=5$ ". Subject S2 generalized base on the example, "according to two example, it is proven that $m 2$ and $n 2$ are divisible by 3 then $m+n$ is divisible by 3 ".

To know that S2 constructed proof base her competency of proving, then we asked to S2, "Are you sure?". S2's response is "I am sure, Sir". It indicated that S2 knew that her proof construction is correct.

\section{Thinking Structure of S1 and S2}

According to explanation above, both thinking structure of S1 and S2 can be form to flow diagram below. Diagram describes both mental structure and mental mechanism in APOS Theory.

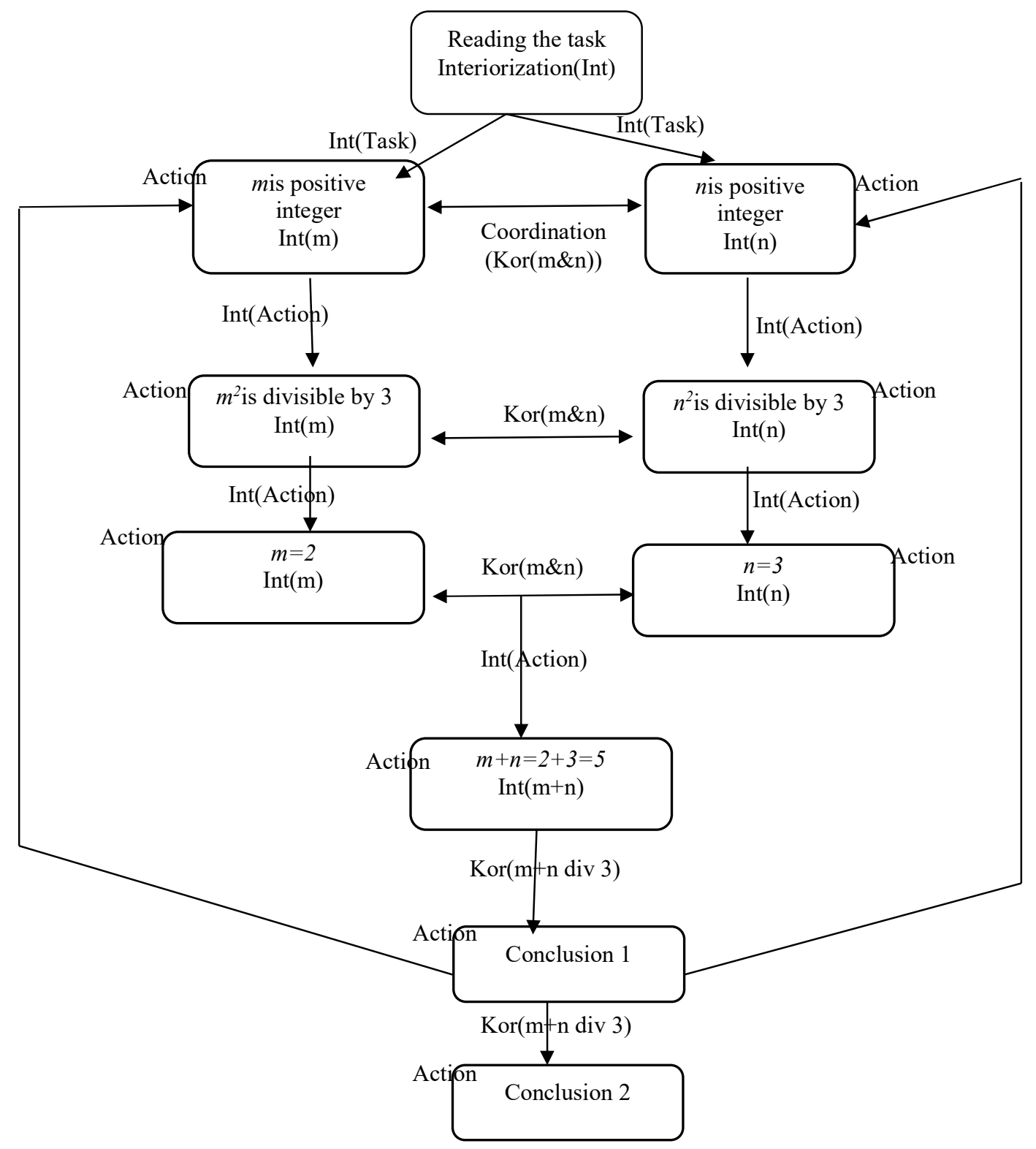

Figure 7. Diagram of thinking structure of S1 and S2 
According to Figure 7, we can conclude that both thinking process S1 and S2 through interiorization ofproblem, interiorization of mathematical object, and coordination. Mental structure of "Action" is created well, but mental structure of "Process" is uncompleted structure. Therefore, both mental structure and mental mechanism can summarized as below (see Figure 8).

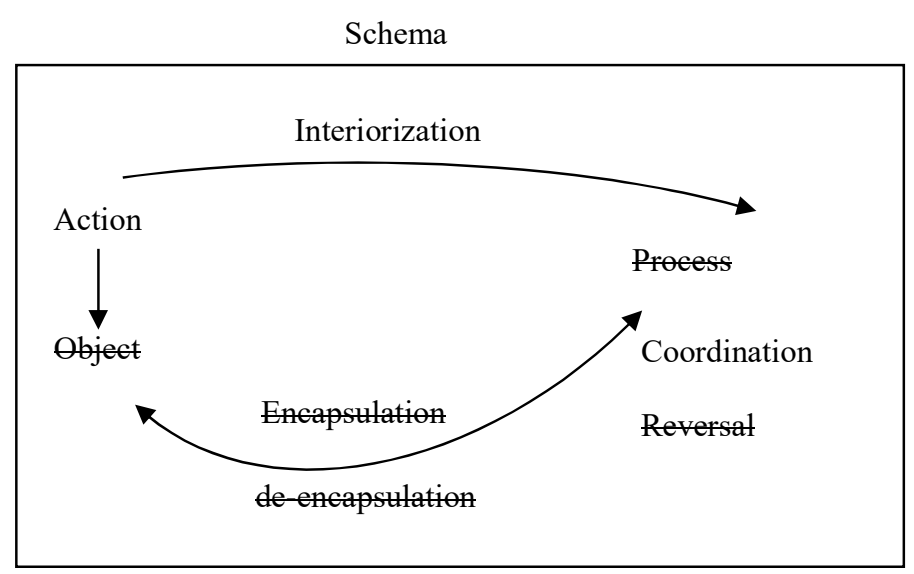

Figure 8. Mental structure and mental mechanism of S1 and S2

\section{Suggested Learning Strategies}

The students' characteristics have no proof-structure, and also have a little conceptual understanding. They have done imperfection "Action', so then they didn't perform interiorization "Action' into "Process". Therefore, the students need assistance to refine a proof-structure and conceptual understanding about proposition. One of method is learning using worked-example (Retnowati, Ayres \& Sweller, 2010; Margulieux \& Catrambone, 2016; McLaren, van Gog, Ganoe, Karabinos \& Yaron, 2016). Weber (2005) stated that proving is a problem solving activity. According to Retnowati et al. (2010), students could understand the material more easily using worked examples than when solving problems. And also, Margulieux and Catrambone (2016) stated that worked-example as guided instruction is important for novices because it helps them organize and use new information more effectively. The students who unable constructing a formal proof is novice students. Worked-example is example how to proving a proposition, and involved arguments in every step.

Students could not construct a formal proof because the encapsulation process was not occured. Therefore, the students need assistance to refine an encapsulation process. Worked-example can refine students' knowledge, 1) how to begin a proof, 2) how to understand about end of proof, 3) how to give argumentation for each step, and 4) how to select mathematical concept is needed. Point 1) and 2) related to refine proof-structure, in addition point 3) and 4) related to refine a conceptualunderstanding. Therefore, we suggest that the encapsulation process will be generated through this method.

\section{CONCLUSION}

Students' characteristics in this study have no proof-structure, and also have a little of conceptual understanding. Therefore, the students were unable to construct a formal proof. An analysis using APOS Theory, they have done imperfection "Action', so then they didn't perform interiorization "Action' into "Process". Mental mechanism

IJEME, Vol. 1, No. 2, September 2017, 135-146 
arises when constructing proof only interiorization and coordination, while encapsulation does not appear. This is why students were not able to construct formal proof. Therefore, the required assistance is to help learn some important lessons that can evoke encapsulation. Therefore the students need assistance to refine encapsulation process. One of method is learning using worked-example.

\section{ACKNOWLEDGEMENTS}

The first author would like to thank to The Ministry of Research, Technology and Higher Education of Indonesia which provides the opportunity to continue his studies in mathematics education study program of Universitas Negeri Malang. This article is a part of research was written by the first author during his study under supervision the other authors.

\section{REFERENCES}

Aziz, T.A., Pramudiani, P., \& Purnomo, Y.W. (2017). How do college students solve logarithm questions?. International Journal on Emerging Mathematics Education, 1(1), 25-40.

Andrew, L. (2009). Creating a proof error evaluation tool for use in the grading of student-generated proofs. PRIMUS: Problems, Resources, and Issues in Mathematics Undergraduate Studies, 19(5), 447-462.

Arnon, I., Cottrill, J., Dubinsky, E., Oktac, A., Fuentes, S.R., Trigueros, M., Weller, K. (2014). APOS theory a framework for research and curriculum development in mathematics education. New York: Springer.

Baker, D., \& Campbell, C. (2004). Fostering the development of mathematical thinking: Observations from a proofs course. PRIMUS: Problems, Resources, and Issues in Mathematics Undergraduate Studies, 14(4), 345- 353.

Cai, J. (2000). Mathematical thinking involved in US and Chinese students' solving of process-constrained and process-open problems. Mathematical Thinking and Learning, 2(4), 309-340.

Creswell, W.J. (2012). Educational research: planning, conducting, and evaluating quantitative and qualitative research - 4th Edition. Boston: Pearson Education.

Dreyfus, T. (1991). Advanced mathematical thinking processes. In David Tall (Eds.), Advanced Mathematical Thinking (pp. 25-41). New York: Springer Netherlands.

Dreyfus, T. (2002). Advanced mathematical thinking processes. In David Tall (Eds.), Advanced Mathematical Thinking (pp. 25-41). New York: Kluwer Academic Publishers.

Dubinsky, E. (2002). Reflective abstraction in advanced mathematical thinking. In David Tall (Eds.), Advanced Mathematical Thinking (pp. 95-126). New York: Kluwer Academic Publishers.

Dubinsky, E., \& Tall, D. (2002). Advanced mathematical thinking and the computer. In David Tall (Eds.), Advanced Mathematical Thinking (pp. 231-248). New York: Kluwer Academic Publishers.

Gibson, D. (1998). Students' use of diagrams to develop proofs in an introductory analysis course.Students' proof schemes. In E. Dubinsky, A. Schoenfeld, \& J. Kaput 
(Eds.), Research in Collegiate Mathematics Education, III, 284-307. Washington: AMS.

Jäppinen, A. K. (2005). Thinking and content learning of mathematics and science as cognitional development in content and language integrated learning (CLIL): Teaching through a foreign language in Finland. Language and Education, 19(2), 147-168.

Kilpatrick, J., Swafford, J., \& Findell. (2002). Adding it-up: Helping children learn mathematics. Washington: National Research Council, National Academy Press.

Margulieux, L.E., \& Catrambone, R. (2016). Improving problem solving with sub-goal labels in expository text and worked examples. Learning and Instruction, 42, 5871.

Mason, J., Burton, L., \& Stacey, K. (2010). Thinking mathematically. Second Edition. London: Pearson.

McLaren, B.M., van Gog, T., Ganoe, C., Karabinos, M. \& Yaron, D. (2016). The efficiency of worked examples compared to erroneous examples, tutored problem solving, and problem solving in computer-based learning environments. Computers in Human Behavior, 55(1), 87-99.

Mejia-Ramos, J.P., Fuller, E., Weber, K., Rhoads K., \& Samkoff, A. (2012). An assessment model for proof comprehensionin undergraduate mathematics. Educational Studies in Mathematics, 79(1), 3-18.

Moore, R.C. (1994). Making the transition to formal proof. Educational Studies in Mathematics, 27(3), 249-266.

National Council of Teachers of Mathematics. (2000). Principles and standards for school mathematics. Reston, VA: The Council.

Retnowati, E., Ayres, P., \& Sweller, J. (2010). Worked example effects in individual and group work settings. Educational Psychology, 30(3), 349-367.

Selden, A. \& Selden, J. (2003). Validations of proofs considered as texts: Can undergraduates tell whether an argument proves a theorem?. Journal for Research in Mathematics Education, 34(1), 4-36.

Sowder, L. \& Harel, G. (2003). Case studies of mathematics majors' proof understanding, production and appreciation. Canadian Journal of Science, Mathematics and Technology Education, 3(2), 251-267.

Syamsuri, Purwanto, Subanji \& Irawati, S. (2016). Characterization of students formalproof construction in mathematics learning. Communications in Science and Technology, 1(2), 42-50.

Tall, D. (1992). The psychology of advanced mathematical thinking: Functions, limits, infinity and proof. In Douglas A. Grouws (Eds.), Handbook of Research on Mathematics Teaching and Learning (pp. 495-514).New York: Macmilan Publishing Company.

Tall, D. (2002).The transition to advanced mathematical thinking. In David Tall (Eds.), Advanced Mathematical Thinking (pp. 3-21). New York: Kluwer Academic Publishers.

Tall, D. (2008).The transition to formal thinking in mathematics. Mathematics Education Research Journal, 20(2), 5-24.

IJEME, Vol. 1, No. 2, September 2017, 135-146 
Weber, K. (2005). Problem-solving, proving, and learning: The relationship between problem-solving processes and learning opportunities in the activity of proof construction. Journal of Mathematical Behavior, 24(3), 351-360.

Weber, K. (2006). Investigating and teaching the processes used to construct proofs. In F. Hitt, G. Harel \& A. Selden (Eds), Research in Collegiate Mathematics Education, VI, 197-232. AMS.

Weller, K., Clark, J., Dubinsky, E., Loch, S., McDonald, M., \& Merkovsky, R. (2003). Student performance and attitudes in courses based on APOS theory and the ACE teaching cycle. In A. Selden, E. Dubinsky, G. Harel, \& F. Hitt (Eds.), Research in Collegiate Mathematics Education, V, 97-131. AMS. 
